\title{
ANALYSIS OF CLASROOM INTERACTION IN EFL CLASS
}

\author{
(1) Asbah, ${ }^{(2)}$ Rajiman \\ (1) Lecturer of English Department University of Muhammadiyah Mataram \\ (2) Student's of English Department University of Muhammadiyah Mataram
}

\begin{abstract}
This study was to find out classroom interaction types and how those types emerge in language teaching process. The research design was a qualitative descriptive. Participants of the research were an English teacher and 25 eight grade students of MTs-Al Raisiyah Sekarbela. The results of the study showed that there were seven types of classroom interactions which were teacher-whole class, teacher- an individual student, teacher-groups of students, student- teacher, student-student, student-whole class, and student-groups of students. The interaction occurred through teacher talk, questioning, giving feedback and discussion.
\end{abstract}

Key words: classroom interaction, teacher talk, questioning and feedback

\section{INTRODUCTION}

Language classrooms interaction can be seen as sociolinguistic environments (Cazden,1988) and discourse communities (Hall and Verplaetse,2000) in which interaction is believed to contribute to learners' language development. According to a review of studies in the area of classroom interaction and language learning presented by Hall and Verplaetse (2000), interactive processes are not strictly individual or equivalent across learners and situations; language learning is a social enterprise, jointly constructed, and intrinsically linked to learners' repeated and regular participation in classroom activities.

It is assumed that the quality and the quantity of teacher talk have many values in student's classroom interaction (Moon, 2000; Richards, 2003). Firstly, it provides language input as language model for learners (Pinter, 2006). Secondly, teacher talk supports student talk in practicing the language. Thirdly, the appropriateness of teacher talk can result in a warm classroom feeling and informal teacher-student relationship. Classroom interaction can be more effective if a variety of teacher and student talk is applied in the classroom. Teachers may accept feeling, praise and 
accept students' ideas instead of merely lecturing, and similarly, students may be encouraged to initiate conversation more, instead of only responding to teachers.

In MTs Al Raisiyah Sekarbela that had been observed by the writer, there are also found out many students with low motivation who did not respond willingly to the teacher's questions and did not participate in class discussion in EFL class. The students regard EFL class is difficult to understand and confused, therefore they fell bored to participation in class discussion. fit this case, the writer will develop research about An analysis of classroom interaction in EFL class to measure the level interaction teacher-student, whether teacher have much role as center or facilitator who convey the material and whether the student involve themselves to receive or active in class when teacher lead learning process. Therefore, the classroom interaction should be observed to get some references in developing interactive language teaching for foreign language classes. As Brown $(2001 ; 168)$ stated, "One way to look at your role as all initiators of interaction in the classroom is to look at yourself (and other teachers) interns of a well-known taxonomy for describing classroom interaction." The classroom interaction will be observed by using categories of teacher's talk, students' talk and teacher's-students talk in the classroom known as FLINT (Foreign Language Interaction).

There are several studies in line with this research. First, Febi.g.p(2013)" conducted research entitled "An analysis of classroom interaction by using Flanders interaction analysis categories system (FIAC) technique " the aim at observing to know percentage teacher and student talk, characteristic, and the both relationship them in SMPN 13 Kota Bengkulu academic year 2013/2014. While the second, Sinta.n.h (2014) "Classroom interaction analysis in the EFL speaking class-aimed at analyzing the categories of teacher talk, student talk and classroom interaction.

The result of the first study conducted by Feby, showed that the teacher talk was the most dominant classroom interaction during the observation. In addition, both teacher $\mathrm{A}$ and $\mathrm{B}$, the content cross was the most dominant characteristics during the observation while the result of the second researcher, based on four times observation that have been conducted at the second semester of English Education Department in the University of Kuningan, it was found that all categories both in teacher talk and student talk as mentioned in FLINT system (Moskowitz, 1971 as cited in Brown, 2001: 170) had been applied by the subjects. The category of "gives information" was mostly used by the teacher and "student specific response" category was most dominant spoken by students.

As the result, this study was interested in investigating what types of classroom interaction applied during EFL class in MTs Al-Raisiyah Sekarbela and How 
Classroom Interaction emerge in language teaching and language process in MTs AlRaisiyah Sekarbela.

\section{METHOD}

This study used qualitative descriptive design. The population of research is teacher and student at the Eight grade of MTs Al Raisiyah Sekarbela in Academic year 2014/2015. Student consists of 25 student in one class and one of teacher. The writer divides the sample become one teacher and students in MTs Al Raisiyah Sekarbela. This researcher took one class namely VIIIA which consist of 25 students as sample.

In collecting the data, the writer chooses two instruments which were observation and interview. For the observation, the researcher used video recorder to record all situation occured in the classroom interaction. In order to get additional information about the problems in classroom interaction, interview both of the teacher and student conducted. The researcher gave question to all samples, which were 25 students and one teacher.

The data collected are analyzed through some steps. The first is segmenting the transcript according to each exchange of interaction. Segmenting is process make note or mapping each interaction occurring in class, based on the result of observation. The next is coding and calculating the amount of each type of classroom interaction adapted from Malamah-Thomas (1987, as cited in Mingzhi, 2005: 59). The third one is analyzing the amount of each category of classroom interaction types in order to find out the occurrence and dominant category used. This is the last step to determining percentage of types of classroom interaction, whether teacher more dominant or instead student more active in class discussion. It can showing who is give influences in EFL class base on types of classroom interaction.

\section{FINDINGS AND DISCUSSION}

\section{Observation}

From the data collection, this research recorded two meetings of Classroom interactions. Each meeting was observed in 30 minutes length. The observed behavior was translated into the descriptive codes. Observation conducting step 1 and step 2 of Foreign Language Interaction Analysis resulted in a table of classroom interaction. The data is presented in the tables below. The data are represent the resulted 
observation from the researcher to determined the intensity of teacher and student talk or initiation in EFL class that are: teacher - whole class, teacher -an individual student, teacher - group members, then student-whole class, student - teacher , student-group member, student- whole class and other( Confuse and silence ).

Based on the first observation, it is found that the classroom interaction occurred in class VIII A by the teacher and student . The types of classroom interaction that include in category of teacher talk that measure the level of interaction in the classroom resulted the amount percentage that determine who are more dominant in the classroom : Teacher - whole class $45.0 \%$, Teacher -an individual student $41.8 \%$, Teacher-group member $13 . .6 \%$. While the types of classroom interaction that include the category of student interaction where student have role to interaction with teacher or among another student. The amount of student talk percentage that are: student -whole class $34.6 \%$, student -teacher $21.8 \%$, student-student $21.8 \%$, student group member $9.0 \%$, and other that is silence and confuse $12.8 \%$.Furthermore based on the second observation category teacher initiated there were teacher -whole class $43.0 \%$, teacher an individual student $42.0 \%$, teacher group members $15.4 \%$ then types of interaction student initiation like: student -whole class $30.6 \%$, student -teacher $19.6 \%$, student student $23.6 \%$, student -group members $11.2 \%$ and other silence or confusion $15.0 \%$.

Based on twice observation that have been conducted at the second grade of MTs Raisiyah Sekarbela, it was found that the types of classroom interaction as categories of teacher talk and student talk as mentioned in FLINT system (Moskowitz, 1971 as cited in Brown, 2001: 170) had been applied by the subjects. The category of teacher initiation in twice observation where teacher - whole, Teacher - an individual was showed the domination in EFL classroom interaction just like that have been present on the table. While student respond or initiation in twice observation were showed the types of student interaction, like student student, student -teacher, student whole class. The three types of student interaction in classroom were gave perception that student enough active in the class although on the second observation the change of student respond was occurred.

\section{Interview}

From interview could be looked the types of interaction between teacher and student and among student - student as the main types of classroom interaction. Here the researcher was interviewed an English teacher and 25 student as participants. The resulted of interview was present on the table below. Here researcher was asked about the conditional how the teacher explained the material, then how often the student respond teacher question or teachers material.

The data interview was represent, the intensity teacher of classroom interaction between student and teacher. The resulted of interview showed teacher 
more active where teacher -whole class were delivered material, give motivation opportunity to student, then student was respond enough active then it make possible classroom interaction emerge.

\section{DISCUSSION}

\section{The types of classroom interaction}

There are seven types of classroom interaction occurred in EFL class according researcher observation like:

a. Teacher-whole class, this type of classroom interaction firstly when the teacher greeted students in the beginning of the lesson and gave the material. Secondly, it was also applied when the teacher gave a several feedback for students' performances in the end of lesson. The last, when the teacher gave information about next teaching learning process activities. The scrip teacher-whole class.

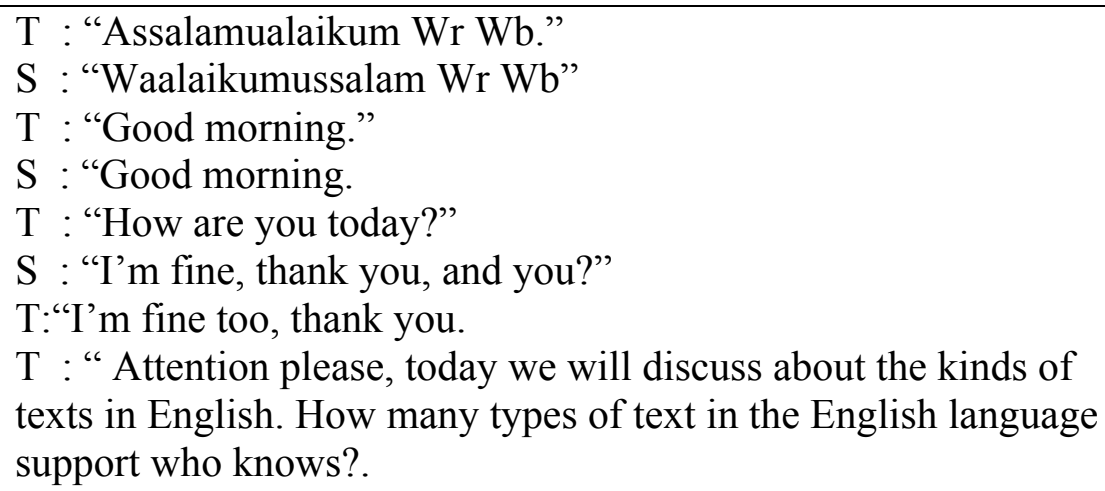

Teacher whole class played the significant role in the classroom interaction, the teacher must be able to know the condition of the item in the classroom exactly student. From the transcript could be looked the teacher open the classroom interaction, teacher begin the classroom with greeting to whole class. It was signed the teacher take the attention of student whole class, it could be the teacher checked student preparation to receive the student delivered in whole class to participation in the EFL class. Teacher played the role in the class to deliver the material to whole class. The teacher explained the material, display question, gave motivation to student then student give respond feedback based on the material that teacher delivered. 
b. Teacher an individual student, this type of interaction applied when the teacher checked students' attendance, directed and asked a student in learning process activities such as ice breaking as a part of communication games. Furthermore, it also applied when the teacher corrected students' mistakes in pronouncing and related to grammatical mistakes as well. Below is the scrip teacher- individual student.

T: "I will check your attendance list, who I call their name say
present. Who is present three times that you say three
present. But if you absent one time, that you present double
present. Be honest, please. Understand all of you?"
S: "Yes.":
T: " Speak up, please. Count your number, please. One, two,
three, four. Back to one, one, two, three, four. Begin from here."

Teacher an individual student became the way for the teacher to more interactive with student. Here teacher should take the opportunity of student to more comprehend known the personality of student in the EFL class. The teacher as the centered of knowledge in the classroom should be able to handle the interaction in the class, it was the key to support the successful teaching learning process. Furthermore teacher used more display question to the student in order the teacher can be made student communicative in respond the material and automatically created the teaching learning process that interest.

c. Teacher group members, this type was used when speaking activity conducted seminar as the example of simulation. In this type of interaction, the teacher told about the score of each group and corrected their mistakes.

T: OK .. Now I divide you into five groups ... .. a group consist of five people you divide or yourself or you need me to divide it ..two desk in front is one group the group.

\section{S: I don't like sir..}

$\mathrm{T}$ : fair let me just make a lot then you select each lot there exist your name and the type of text that you have get Ok. Two groups will get the same text types as a 
.This will presentation on Saturday. It could be present in the English or Indonesia but English will be better ok.

S: ok pack.

T: Yusuf's group will get descriptive, ilham's group get narrative teks his group, anita's group get reqount text, while izlayana's group get descriptive same like the first group but should not be the same then the last group text procedures. Remember to be cooperative !!

Teacher - group members was situation where the teacher divide the student in more group, the teacher there has function as the controller. The teacher gave more topic for each group and then the student can be worked together with other student in one group. Here student was more time for student to explored their idea based on clue or material that have been given. The important role for the teacher in taught whole class where teacher was criticized and corrected the mistake of every group performance. The teacher can be said gave simulation for student activity then group of student feel easy to take role in the EFL class.

d. Student teacher, this type refers to the student's initiation to ask or interact with the teacher. It occurred in the last meeting when the students performed their speaking in front of their classmates. Students interacted with the teacher when they tried to present and to ask some vocabularies which they did not know in the target language. In addition, it was applied when they asked the teacher about speaking activities in the following meeting.

S: goat sir .while sir, what the English of bunga mawar?

$\mathrm{T}$ : Other ad else there is to know?

S: Jasmin sir ..

$\mathrm{T}$ : no, the English language of bunga mawar is ROSE .

S: ok sir, for those who do not have a plant or animal in its home how are sir?

$\mathrm{T}$; yes describe any animal. Give time 15 minutes, each group had to describe two animals or plants your favorite okk ... then each group will represent by one member of group in front of the result their work: 
This types of classroom interaction that give opportunity to student to interact with their teacher. The student had feel to initiate or explored their idea based on the material discussed by teacher, here the student can be respond teacher material that delivered then student develop their idea into more question or explanation that can be said as student response or initiated. In the scrip showed the student was initiated with asked based on the material that have been delivered by the teacher. It possible teacher gave respond with explained more detail and comprehensive the material, in this situation was occurred the types interaction student teacher, where student as initiator with appeared their idea about material.

e. Student student, this type of interaction is called pair work and it occurred when the classroom conducted simulation and communication games activities. Below is the scrip student-student.

$\mathrm{S}$ : what is your favorite animal?

S2: my favorite animal is cat and you?

$\mathrm{S}:$ my favorite animal is rabbit..

S2: why do you like cat?

$\mathrm{S}$ : because he cute and you?

S2: because she beautiful .

Student student is the type of interaction with find out other student became pair or collaborative interaction, the activity of student student should be arranged by teacher. Role of the teacher here as simulator to direct student activity. Student interaction was condition where the student should be given more opportunity to interaction other student. Student interaction can be said as pair work, the teacher determine the pair then student were change their main thorough the conversation . This types was possible the student can be improved communication skill in classroom interaction, developed, improve their confidence although they did not use English with correct.

f. Student group members, the classroom interaction activities which applied this type were class discussion in the first meeting and communication games in the more meeting. Below is the scrip student group members. 
$\mathrm{S}$; today we will discuss about the text procedures. From the results of the discussion we will use procedures cooking noodles. The next friend we will deliver the noodles cook procedure. for other groups who want to ask .please ask after our group delivered material.

Student group members was identical with group work, student can be made collaboration to self initiated language. Then teacher acted as the organizer for giving student information then student discussion in classroom, student group member became the pattern to develop the ability of student accepted more idea from other group.

g. Student whole class, this type was applied when students performed in front of the class as the presenters in class discussion, speakers in simulation, and performer in communication games. This interaction gave the same opportunity for each student to speak during speaking class.

S : we will presentation the result of our discussion: I Have chicken ,she is beautiful, she has white fur, she like eat corn then the second. I Have cat, he has black fur, I call his shinta, he like fish.

S : I have goat, he have beard, he have four leg, just it sir. The next I have rabbit, he likes eat vegetable, he has beautiful fur.

Student whole class is the area of student to talk in front of the class, teacher and other student. Student have more opportunity to built their confidence to open the interaction in the class to make student as second part of the class became appeared. Student whole class can be supported student enough active in the class, it proved student not monotone in the EFL class as the receiver of knowledge but they delivered their idea in just like the centered it can be said student initiated. When they talk in front of the class or take part in the class automatically resulted the role of interaction become improved in EFL class.

Based on the representation of the data observation, it can be seen teacher more dominant than the student in EFL class interaction. Teacher has role as initiated or centered in class. The domination by 
teacher looked through teacher whole class, where teacher initiated with explained the material, the teacher asked a display question, the teacher explained the meaning of word, phrase or sentence and teacher always checked for student understanding to whole class. The level of teacher interaction in the class could be proved based on the amount of percentage in the first observation that is $45.0 \%$. Beside the teacher whole class was high intensity in EFL class but can be seen the teacher an individual student gave domination. This is the role of teacher used personality interaction in deliver the material. The types of classroom interaction where the teacher explained material then checked individual student understanding or respond, criticizes, give encourages, give respond to student mistake and teacher asked student opinion. The amount of percentage teacher- an individual student that is $41.8 \%$.

Despite the teacher that is more dominant in the classroom, the student played the important role in the EFL class in talking -response and talking initiation in EFL class could be said the student enough active in the EFL class. The types of classroom interaction that support the student enough active, it can be seen on the observation table there were student whole class, student teacher and student student. Student whole class where the student used the opportunity that have been given by teacher, like the teacher made a group discussion then one of them should be presentation or explored their idea with loudly in front of the class then student asked a question regarding understandability of words, phrases, or sentence during whole class discussion. The teacher whole class can be proved on the amount of percentage $34.0 \%$ in the observation table. Furthermore student teacher this types refers to student initiation to ask or interaction with the teacher. This situation where student perform orally in the class without asked based on teacher instruction then student teacher asked teacher if did not understand about the material that teacher have explained. Then the last type to proved student have role in the class is student - student, this types of interaction could be said pair work. The student interaction with other student in the class that make classroom became interactive , because they could be changed their main in class discussion. The situational student-student was interaction in EFL class if student asked other student opinion, student ask other student if didn't understand about the material . 
Between student teacher and student-student had the same percentage that are $21.8 \%$. The role of interaction between teacher and student showed teacher more dominant then student enough active to respond the teacher material in classroom although the student not more able showed to initiated to created communicative and interactive in EFL class because student consider EFL class is difficult.

\section{How the classroom interaction occured}

The classroom interaction emerged in the language teaching process is a situation that will be discussion because the teacher and the student become the determiner in the class. Teacher and student have the important role in EFL class, the teacher as initiator to lead the class discussion while the student as participator that give respond about the material, from the way of interaction both of them it was possible classroom interaction emerge. The researcher conducted interview to know the classroom interaction emerge. Below is the script interview.

If I asked student about the material that have been delivered, they usually give respond and gave question when they did not understand about the material it will be explain the material more comprehensives till they understand. I always give them motivation almost every time in teaching learning process, I think giving motivation is to encourage student to be more active. I also gave opportunity for student to interaction with me and it looked effective they enough active in the class, they were brave to ask. I often asked student to speak English in front of the class but usually the first they were shy, they were afraid false but I gave encourage then they perform and made EFL class more fun. Classroom interaction was occurred in the class although not more interactive but student enough give response.

Teaching learning process in the class absolutely was involve teacher and student, the successful of class was determine the role of teacher as the centered of knowledge and the rule of student as receiver of knowledge.

Based on the interview scrip could be seen, classroom interaction emerged thorough the intensity of teacher talk like teacher whole class, teacher an individual student, this type gave more opportunity for teacher to 
explained the material, give motivation, measure the level of question difficult or easy after that student respond the teacher material, student expressed their opinion, answered the question. The classroom activity started the teacher explained the material then student respond, it showed continuous interaction in the class. Furthermore classroom interaction emerge not only based intensity of teacher talk like display question then student respond but classroom emerged thorough approached, like emotional approach, individual approach. This condition made the student more comfortable to interaction with teacher, there were no afraid, when student comfort automatically student showed their interaction.

The types of question, the intensity of teacher delivered, give the question, give opportunity to student, thorough the teacher talk or initiation in the classroom it gave opportunity for student to give feedback, or respond. It was possible teacher and student to take the role in the class, student can be taken the role to initiated like more types student interaction, exactly student whole class, student teacher and student student. Teacher checked how student preparing in language teaching and process in EFL class, mostly student learn English as foreign language usually could be appeared any kind reason to student itself. One of the student expressed, English is difficult to pronounce. However, teacher play the significant role in the class with try to adaptation with student to begin with smile, give motivation, building confidence, that are the main point to create interactive class that not monotone toward teacher as facilitator of knowledge in EFL class. Teacher was gave more information, explain material with clearly, gave motivation, teacher had prepared good material. So from the data interviews could be seen classroom interaction emerge based on how much teacher gave opinion, gave question, and teacher open the opportunity for student, automatically with spontaneous there were student respond the material then classroom interaction emerged through collaborative exchange of teacher talk and student talk that occurred continuous during EFL class.

\section{CONCLUSION AND SUGGESTIONS}

The objective of this research is to describe all point of types classroom interaction, the types of classroom interaction that include in the category of teacher talk and student talk in the process of English teaching learning at the 
eighth grade of MTs Al-Raisiyah Sekarbela. Based on the findings and discussion in the previous chapter, it can be concluded that:

1. There were seven types of classroom interaction teacher whole class, teacher an individual student, teacher group members, student student, student teacher, student whole class, student group members. The each types of classroom interaction have role that support the successful of the classroom interaction. Among the seven types of classroom interaction the category of teacher initiated teacher whole class, and teacher and individual have the significance role while the category student initiated student teacher, student student, and student whole class has the important role to support classroom more active.

2. The classroom interaction was emerged through intensity of teacher talk that explained the material with clearly, give display question, give motivation and opportunity to student then the student gave responses toward material that teacher delivered during the teaching learning process occurred. Despite there were no willingness from the student to initiated the material to interaction with teacher in the class but the teacher able handle with give motivation, give easier question to respond by student, it was created the interactive pattern that make classroom interaction emerge.

\section{REFERENCES}

Brown, H. D. (2001). Teaching by Principles: An Interactive Approach to Language Pedagogy. Second Edition. New York: Addison Wesley Longman, Inc.

Cohent.I: 2011: Teacher-.student interaction in classrooms of students with specific learning difficulties learning English as a foreign language: equinox publishing

Douglas. C. A: 2006: Classroom oral interaction in foreign language lessons implications for teacher development.

Dagarin.M:2004:Classroom interaction and communication strategies in learning English as foreign: 138

Febi.g.p:2013: Conducted research entitled "An analysis of classroom interaction by using Flanders interaction analysis categories system (FIAC) technique

Jack R. Fraenkel and Norman E.Wallen. 2006. How to Design and Evaluate Research in Education. San Francisco: McGraw-Hill companies. 
Mingzhi, X. :2005: Enhancing interaction in our EFL classroom. CELEA Journal Vol. 28 No. 2, pp. 56-62

Mulyadi.D:2001: Teacher talk modes in English as a foreign language classroom interaction

Murdech.Y:1990: Observation of an English Language Classroom

Mujahidah: 2011: The descriptive study on the classroom interaction during the English-teaching learning process

Moskowitz, G. (1971). Interaction Analysis: A Mew Modern Language for Supervisors. In: Brown (2001). Teaching by Principles: an Interactive Approach to Language Pedagogy. Second Edition. New York: Addison Wesley Longman, Inc.

Nazara, S:2010: Students' perception on EFL speaking skill development: academia.edu/776982/Students_Perception_on_EFL_Speaking_Skill_Develo pment Riani.P.T:2013:An analysis of teacher talk and student talk in in English for young learners (EYL)

Sandelowsky.M:2000:Focus on research methods.

Sinta.n.h :2014: in her research entitled Classroom interaction analysis in the FFL speaking class"

Sugiono:2014 : Metode penelitian pendidikan.-pendekatan kuantiatif,kualitatif', $R$ dan D: 117-118: published:Alfabeta Bandung

Tuan, L.T., \& Nhu, N.T.K. :2010:. Theoretical review on oral communication in EFL classrooms. Studies in Literature and Language Journal Vol. 1., No. 4, 2010, pp. 29-48.

Thapa, C. B. \& Lin, A. M. Y. (2013). Interaction in English language classrooms to enhence students language learning. Retrieved April 12, 2015 from http://neitaclioutari.wordpress.com./20I3/0/0I/interaction-in-englisblaiiguageclassrooms-to-enhance-nepalese-students-language-learning

Yassmine.P:2009: Classroom discourse analyzing teacher learner interaction in Iranian EFL task based haled of classroom

Xiao.L:2014: Investigating the communicativeness of classroom teacher-student interaction from a conversation analysis perspective. 